\title{
Are marine planktonic invertebrates food limited? The functional response of Mysis mixta (Crustacea, Mysidacea) in the Baltic Sea
}

\author{
M. Ali Mohammadian ${ }^{1,2}$, Sture Hansson ${ }^{3, *}$, Bart T. De Stasio $^{2,4}$ \\ ${ }^{1}$ Cornell University Biological Field Station, Cornell University, Dept of Natural Resourses, 900 Shackelton Point Rd, \\ Bridgeport, New York 13030-9750, USA \\ ${ }^{2}$ Biology Department, Lawrence University, PO Box 599, Appleton, Wisconsin 54912-0599, USA \\ ${ }^{3}$ Department of Systems Ecology, Stockholm University, S-10691 Stockholm, Sweden \\ ${ }^{4}$ Center for Limnology, University of Wisconsin, Madison, Wisconsin 53706-1492, USA
}

\begin{abstract}
The mysid shrimp Mysis mixta is an important zooplanktivore in the Baltic Sea and has been suggested to contribute in structuring the zooplankton community. To describe this predation quantitatively, its functional response was determined in laboratory feeding experiments using as prey a sample of the natural zooplankton assemblage from the Baltic Sea. Experiments were made in darkness in $27 \mathrm{l}$ black plastic bags, incubated $24 \mathrm{~h}$ at $13^{\circ} \mathrm{C}$ and with prey concentrations between 7 and 300 ind $\mathrm{I}^{-1} \mathrm{M}$. mixta was a selective predator, consuming prey in the following preference order: Pseudocalanus juvenules $\approx$ Acartia adults $\geq$ Bosmina $=$ Acartia juveniles $>$ Eurytemora adults $\approx$ Eurytemora juveniles. A Type II functional response model was fitted to consumption data, although the saturation level (i.e. maximum consumption rate) was not reached in the experiments. Combining a bioenergetics model, the individual in situ growth rate of $M$. mixta and our functional response model indicates that ambient abundances of zooplankton (10 to 20 ind. $\mathrm{l}^{-1}$ in August, which is the annual maximum) are too low to maintain observed growth rates without taking prey patchiness into account. To explain the observed growth of $M$. mixta in the Baltic Sea, zooplankton patches with densities 3.5 to 6 times that of average ambient densities are necessary. The consumption rates also indicate that even when the zooplankton abundance is at its annual maximum, Baltic Sea $M$. mixta is food limited.
\end{abstract}

KEY WORDS: Mysis mixta $\cdot$ Functional response $\cdot$ Zooplankton $\cdot$ Prey selectivity $\cdot$ Baltic Sea

\section{INTRODUCTION}

Much ecological research is aimed at improving our understanding of the effects of trophic interactions in structuring natural communities and ecosystems. This interest in trophic interactions has a long history and has been an important basis of studies for many decades (e.g. Lindeman 1942, Hairston et al. 1960, Hairston \& Hairston 1993). In recent years, concepts such as 'top-down', 'bottom-up' and 'cascading trophic' interactions (Carpenter et al. 1985) have revitalized this research and made it a central theme in

\footnotetext{
- Addressee for correspondence

E-mail: sture_h@system.ecology.se.su
}

ecology (e.g. see the 'Special Feature' section in the June 1992 issue of Ecology).

To understand food web structure and dynamics, knowledge of limiting factors for different organisms is crucial. If food consumption by a species is limited by factors other than food availability, the consumer will be unable to respond to changes in food abundance. Under such circumstances, the consumer will have no direct effect on food web dynamics; marine zooplankton may be one example of this. Huntley \& Boyd (1984) and Huntley \& Lopez (1992) suggest, based on literature reviews, that marine zooplankton growth (mainly for copepods but also for other groups such as krill) is generally limited by temperature and not food. This perspective has, however, been questioned by Kleppel 
et al. (1996, see also references therein and the response by Huntley 1996), and in an earlier article (Hansson et al. 1990 b) we reported on field data indicating food limited growth of the mysid shrimp Mysis mixta Lilljeborg in the Baltic Sea.

One approach for evaluating whether or not a consumer can be expected to be influenced by food availability is to determine its functional response (Holling 1959). If the in situ food abundance is so high that the consumer has likely reached its consumption plateau (maximum food consumption), it is no longer food limited. In this paper, results from functional response experiments with Mysis mixta and its natural zooplankton prey are reported. These experiments support our eariler finding (Hansson et al. 1990b) that $M$. mixta in the Baltic Sea is food limited, and the results also imply that the mysid is dependent on patchily distributed prey

\section{MATERIALS AND METHODS}

This study was conducted in the northern Baltic proper $\left(58^{\circ} 49^{\prime} \mathrm{N}, 17^{\circ} 35^{\prime} \mathrm{E}\right)$, where the pelagic community is comparatively simple (Elmgren 1984) and hence well suited for analyses of food web interactions. There are only 3 dominant zooplanktivores in this area: herring (Clupea harengus L.), sprat [Sprattus sprattus (L.)] and a mysid shrimp (Mysis mixta Lilljeborg) (Hansson et al. 1990a, Rudstam et al. 1992, Arrhenius \& Hansson 1993). The 4 experiments reported on in this article were conducted during the period August 7 to 23, 1993, which is the time of year when the Baltic Sea zooplankton biomass, and consequently mysid prey availability, peaks in this coastal area (Johansson et al. 1993) as well as in the Baltic proper in general (Hernroth \& Ackefors 1979)

Mysid and zooplankton collection. All animals were collected the night before the experiments were started, using a plankton net (mesh size $90 \mu \mathrm{m}$ ) which was pulled below the thermocline and between 17 and $32 \mathrm{~m}$ (bottom depth of 25 to $35 \mathrm{~m}$ ). Within $3 \mathrm{~h}$ after being captured, the musids were placed in sandfiltered seawater $\left(13^{\circ} \mathrm{C}\right)$ without food for 12 to $16 \mathrm{~h}$ before the experiments. Only mysids 15 to $17 \mathrm{~mm}$ in length and which appeared healthy at the end of this period were used.

Within 2 h of collection, the zooplankton to be used as prey were transferred to a large aquarium containing approximately $700 \mathrm{l}$ of $12^{\circ} \mathrm{C}$ sea water. After $12 \mathrm{~h}$, the surface of the aquarium was skimmed with a $90 \mu \mathrm{m}$ mesh sieve to remove cladocerans trapped by surface tension, while the bottom of the aquarium was siphoned to remove dead zooplankton. By diluting this 'zooplankton concentrate' with sand-filtered sea

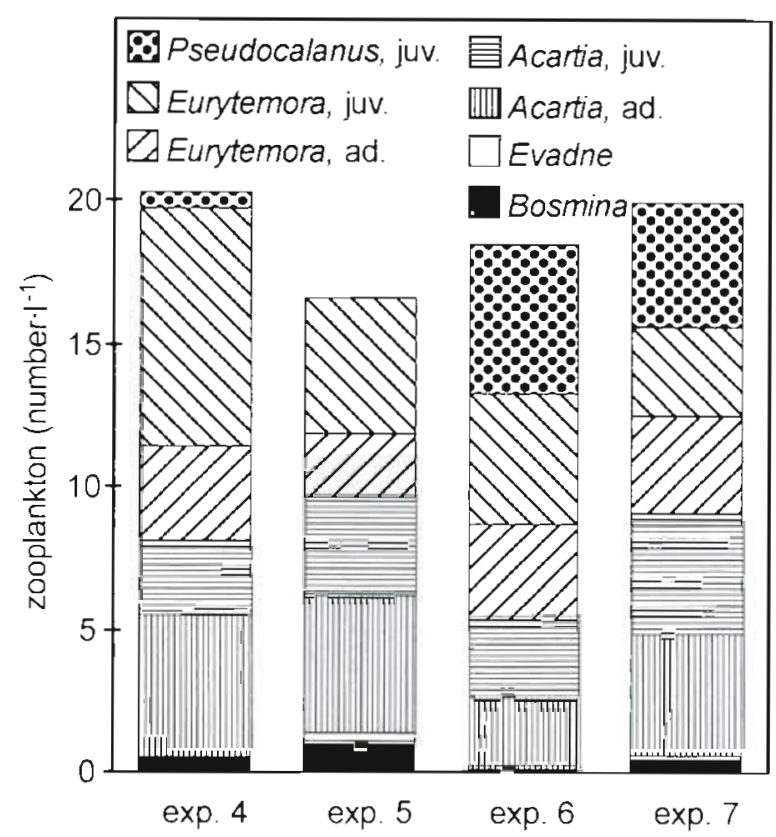

Fig. 1 Zooplankton density and species composition in the start bags ( $1 \times \mathrm{S}$ in Table 1). Evadne and Bosmina are cladocerans and the remaining genera copepods

water, we created a zooplankton density gradient in each experiment. This density gradient ranged from ca $1 / 3$ to 15 times the ambient zooplankton density, which is $\sim 20$ ind. $\mathrm{I}^{-1}$ at the depths in which mysids occur during July and August (Rudstam et al, 1989, Hansson et al. 1990a, Johansson et al. 1993). The zooplankton were strongly dominated by copepods (Fig. 1), which is normal for this area (Johansson et al. 1993). Hardly any naupliar stages of copepods occurred in the samples, as these are mainly above the thermocline (Hansson et al. 1990a).

Experimental procedures. The experiments were conducted in suspended black, non-transparent polyethylene bags. To each bag, we added $26.6 \mathrm{l}$ of the sand-filtered sea water with different densities of zooplankton (see above). Ten mysids were also added to all bags, except for 'start hags' and 'rontrol bags' (see below). The air was removed from each bag, which was then closed and incubated for $24 \mathrm{~h}$ ( $3 \mathrm{~h}$ for start bags) at $13^{\circ} \mathrm{C}$, which is in the upper range of temperatures encountered by Mysis mixta during the summer months in this part of the Baltic (Rudstam et al. 1989, Hansson et al. 1990a). The $24 \mathrm{~h}$ incubation period was used to eliminate possible effects of diel variation in feeding (e.g. Cooper \& Goldman 1982). Preliminary experiments, as well as later studies (Gorokhova \& Hansson in press), indicate that the feeding rate of $M$. mixta is at least as high in darkness as in light, and with the relatively large volume used, the container 
size probably had no or only marginal effects on feeding rates. A summary of the experiments is given in Table 1

The start bags were used to estimate starting densities of zooplankton, and these bags were sampled (as described below) as soon as the incubation of the other bags had started. The control bags were used to determine the mortality of zooplankton in the absence of mysids, and they were treated in the same way as the bags with mysids.

After 24 h of incubation, each bag was cut open, rinsed and the water filtered through a $90 \mu \mathrm{m}$ mesh. Mysids were classified as alive or dead and their dry weight was determined by drying at $60^{\circ} \mathrm{C}$ to a constant weight. The carbon content of Mysis mixta was assumed to be $40 \%$ of the dry weight (Mauchline 1980). The dominant zooplankton were counted and classified into groups (Table 2).

Calculations. The background mortality rate of zooplankton was estimated from differences between start and control bags. This background mortality was on average $7 \%$. In bags with mysids, the decrease in zooplankton was on average $37 \%$, so the dominant cause of mortality in these bags was predation. It is possible, however, that the mysids also fed on already dead or dying zooplankton, which is included in the background mortality. We estimated the mysid food consumption rates from the average zooplankton density of start and control bags. A pilot experiment without mysids and with 4 zooplankton densities ( $1 / 3 x, 1 \times, 3 x$ and $9 \times$ ambient zooplankton density) and 5 replicates each, did not indicate any density-dependent background mortality.

To standardize consumption rates, taking into account both size differences among the zooplankton and variation in mysid size, both consumption and zooplankton densities are given in carbon weight instead of number (individual carbon biomasses of zooplankton are given in Table 2). For each bag containing mysids, the daily weight-specific consumption (g C

Table 1. Experimental design in studies of the functional response of Mysis mixta from the Baltic Sea. Experiments were conducted in black plastic bags with a volume of 26.61 , with 10 mysids added to each bag except for the start and control bags to which only zooplankton was added. Expts 1 to 3 were pilot studies on effects of incubation container size, light conditions during the experiment and possible density dependence in the background mortality of zooplankton. Mysid weights given are average individual dry weights (DW). Zooplankton densities are given as no. $\mathrm{l}^{-1}$, with standard deviations given for start and control bags. The variation was much higher among bags incubated with mysids, and this variation is reported as standard errors in Fig. 2 . 'Prey decline' shows the decrease in zooplankton biomass during incubation. Abbreviations in the 'Density treatment' column are: $A x=$ density treatment factor, approximately $A$ times the ambient zooplankton abundance; $C=c o n t r o l$ bag, incubated $24 \mathrm{~h}$ without mysids; $\mathrm{S}=$ start bag, treated like the control bags, but incubated for only $3 \mathrm{~h} ; \mathrm{M}=$ incubated $24 \mathrm{~h}$ with 10 mysids

\begin{tabular}{|c|c|c|c|c|c|c|}
\hline Expt & $\begin{array}{l}\text { Date and } \\
\text { mysid DW }\end{array}$ & $\begin{array}{c}\text { Density } \\
\text { treatment }\end{array}$ & $\begin{array}{l}\text { No. of } \\
\text { replicates }\end{array}$ & $\begin{array}{l}\text { Zoopl. } \mathrm{l}^{-1} \\
\text { mean }\end{array}$ & $\begin{array}{c}\text { Prey decline } \\
(\%) \text {, mean }\end{array}$ & $\begin{array}{l}\text { Incubation } \\
\text { time }(\mathrm{h})\end{array}$ \\
\hline \multirow[t]{6}{*}{4} & A.ug $7,6.0 \mathrm{mg}$ & $1 \times S$ & 4 & $21.1 \pm 0.8$ & - & 3 \\
\hline & & $1 \times C$ & 4 & $19.5 \pm 0.8$ & 11 & 24 \\
\hline & & $1 / 3 \times M$ & 3 & 7.0 & 45 & 24 \\
\hline & & $1 \times M$ & 5 & 21.1 & 41 & 24 \\
\hline & & $3 \times \mathrm{M}$ & 5 & 63.3 & 34 & 24 \\
\hline & & $9 \times \mathrm{M}$ & 5 & 190 & 26 & 24 \\
\hline \multirow[t]{6}{*}{5} & Aug $12,6.8 \mathrm{mg}$ & $1 \times S$ & 5 & $15.7 \pm 2.7$ & - & 3 \\
\hline & & $1 \times C$ & 5 & $16.9 \pm 1.3$ & 3 & 24 \\
\hline & & $1 / 3 \times M$ & 4 & 5.2 & 33 & 24 \\
\hline & & $1 \times M$ & 5 & 15.7 & 37 & 24 \\
\hline & & $3 \times M$ & 5 & 47.1 & 34 & 24 \\
\hline & & $9 \times M$ & 5 & 141 & 21 & 24 \\
\hline \multirow[t]{7}{*}{6} & Aug $20,7.4 \mathrm{mg}$ & $1 \times \mathrm{S}$ & 3 & $19.2 \pm 0.7$ & - & 3 \\
\hline & & $1 \times C$ & 4 & $18.6 \pm 1.7$ & 4 & 24 \\
\hline & & $1 \times M$ & 3 & 19.2 & 58 & 24 \\
\hline & & $3 \times \mathrm{Ml}$ & 4 & 57.7 & 56 & 24 \\
\hline & & $5 \times M$ & 4 & 96.1 & 46 & 24 \\
\hline & & $9 \times M$ & 4 & 173 & 40 & 24 \\
\hline & & $15 \times M$ & 4 & 288 & 30 & 24 \\
\hline \multirow[t]{7}{*}{7} & Aug $23,7.2 \mathrm{mg}$ & $1 \times S$ & 4 & $22.5 \pm 2.1$ & - & 3 \\
\hline & & $1 \times C$ & 4 & $19.8 \pm 2.6$ & 11 & 24 \\
\hline & & $1 \times M$ & 4 & 22.5 & 44 & 24 \\
\hline & & $3 \times M$ & 4 & 67.5 & 36 & 24 \\
\hline & & $5 \times M$ & 4 & 112 & 32 & 24 \\
\hline & & $9 \times \mathrm{M}$ & 4 & 202 & 34 & 24 \\
\hline & & $15 \times \mathrm{M}$ & 4 & 337 & 29 & 24 \\
\hline
\end{tabular}


Table 2. Predominant groups of zooplankton, which together constituted $>98 \%$ of the number of potential prey in the experiments. Individual biomasses, in $\mu \mathrm{g} \mathrm{C}$ ind ${ }^{-1}$, are from Kankaala (1987)

\begin{tabular}{|lc|}
\hline Species and age stage & $\begin{array}{c}\text { Bio- } \\
\text { mass }\end{array}$ \\
\hline Cladocerans & \\
Bosmina longispina maritima (P. E. Müller), adult & 0.80 \\
B. I. maritima, juvenile & 0.61 \\
Evadne normandil Lovén & 1.43 \\
Podon spp. & 0.42 \\
Copepods & \\
Acartia bifilosa Giesbrecht and & \\
A. longiremis Lilljeborg, adult female & 2.81 \\
A. bifilosa and A. longiremis, adult male & 1.88 \\
A. bifilosa and A. longiremis, copepodite IV-V & 2.13 \\
A. bifilosa and A. longiromis, copepodite I-III & 0.68 \\
Eurytemora affinis (Poppe), adult female & 2.81 \\
E. affinis, adult male & 1.88 \\
E. affinis, copepodite IV-V & 2.13 \\
E. affinis, copepodite I-lII & 0.68 \\
Pseudocalanus minutus elongatus (Boeck), adult & 4.69 \\
P. m. elongatus, juvenile & 1.43 \\
&
\end{tabular}

$\left.\mathrm{g}^{-1} \mathrm{C} \mathrm{d}^{-1}\right)$ was estimated using the formula below. Consumption was estimated for both total zooplankton and for each taxonomic group.

$$
C R_{i, n}=\frac{A \times Z_{\text {control, },}-Z_{\text {mysid, }, n}}{\frac{M_{\text {start, }, n}+M_{\text {stop }, i, n}}{2} \times W_{1, n}} \times 26.6
$$

where $C R_{i, n}=$ the weight-specific consumption rate of mysids in bag $n$ in experiment $i\left(\mathrm{~g} \mathrm{C}^{-1} \mathrm{C} \mathrm{d}^{-1}\right) ; A=$ the density treatment factor $(1 / 3$ to 15 , see Table 1$)$; $Z_{\text {control, } i}=$ the average zooplankton density $\left(\mathrm{gCl}^{-1}\right)$ in the start and control bags $(1 \times S$ and $1 \times C)$ in experiment $i_{i} Z_{\text {mysid, } i, n}=$ zooplankton density $\left(\mathrm{g} \mathrm{C}^{-1}\right)$ at the end of the incubation in the Mysis-containing bag $n$ in experiment $i ; M_{\text {start }, i, n}=$ number of mysids in bag $n$ at the start of experiment $i$ (always 10 ), $M_{\text {stop }, i, t,}=$ number of mysids in bag $n$, experiment $i$, at the end of the incubation (usually 10 , only $1 \%$ of the mysids died during the experiments): $W_{i, n}=$ average weight $(\mathrm{g} \mathrm{C})$ of a mysid in bag $n$ in experiment $i ; 26.6=$ the bag volume, as zooplankton densities are given per litre.

As the zooplankton density decreased during the incubation period, consumption rates were correlated to the estimated density in the middle of the incubation period. Assuming a constant instantaneous mortality rate, this abundance was calculated as:

$$
Z_{\text {mean }, i, n}=\mathrm{e}^{\left.\frac{\ln \left(A \times Z_{\text {start }, i}\right)+\ln \left(Z_{\text {mysid } i, n}\right)}{2}\right)}
$$

where $Z_{\text {start }, i}$ is the average zooplankton density in the start bags in experiment $i$ and the other parameters are as defined above. If the mysids have a functional response of Type II (Holling 1959), as assumed below, their efficiency will increase as the prey abundance decreases and the equation above will underestimate average prey abundance. However, simulation analyses (authors' unpubl.) showed that with the relatively linear relationships that we found between prey abundance and consumption, these underestimations were at most a few percentage points and thus they will not significantly influence our conclusions.

Using the nonlinear regression module in SPSS for Windows (release 7.0), functional response models of Type II (Holling 1959, Begon et al. 1990) were fitted to the consumption rates $(C R)$ at different zooplankton densities $\left(Z_{\text {mean }}\right)$ :

$$
C R=\frac{k_{1} \times Z_{\text {mean }}}{1+k_{2} \times k_{1} \times Z_{\text {mean }}}
$$

where the constants $k_{1}$ and $k_{2}$ measure the prey capture rate and prey handling time respectively. When estimating prey capture rates for the different prey categories a linear model $\left(C R=k_{1} \times Z_{\text {mean }}+k\right.$, where $k$ is the intercept; linear regression module in SPSS) was applied, as consumption data at this taxonomic level were generally so scattered that no tendencies of decreased consumption rates with increased prey densities could be seen. Instead of using indirect estimates of relative prey 'preferences', such as the Ivlev or Chesson indices (Ivlev 1961, Chesson 1983), we use the prey capture rates $\left(k_{1}\right)$ of different prey to describe the 'preferences' of the mysid.

\section{RESULTS AND DISCUSSION}

In all experiments, the food consumption of Mysis mixta increased significantly with increased prey density (Fig. 2). The differences among the 4 experiments were small and the $95 \%$ confidence intervals for the functional response constants $\left(k_{1}\right.$ and $k_{2}$ ) overlapped among the experiments. Though we manipulated zooplankton densities over a large range, up to $15 \times$ ambient zooplankton abundances, we were unable to detect food saturation levels. As we never reached saturation levels, the estimated values of $k_{1}, k_{2}$ and maximum food consumptions (Fig. 2) must be interpreted with caution. The range of estimated maximum consumption rates $\left(0.19\right.$ to $0.41 \mathrm{~g} \mathrm{C} \mathrm{g}^{-1} \mathrm{C} \mathrm{d}^{-1}$, for mysids of

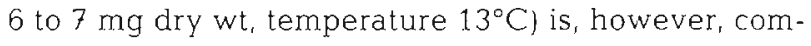
parable to estimates presented in other studies. Toda et al. (1987) found that 6 to $7 \mathrm{mg}$ dry wt individuals of Neornysis intermedia, at temperatures between 10 and $15^{\circ} \mathrm{C}$, had maximum consumption rates of 0.1 to $0.3 \mathrm{~g} \mathrm{C}$ $\mathrm{g}^{-1} \mathrm{C} \mathrm{d}^{-1}$ For $\sim 5 \mathrm{mg}$ dry wt Neomysis mercedis at $10^{\circ} \mathrm{C}$, 
Chigbu \& Sibley (1994) reported maximum consumption rates of 0.7 to $1.6 \mathrm{~g}$ $\mathrm{C}^{-1} \mathrm{C} \mathrm{d}^{-1}$ (as stressed by the authors these values might be overestimates as they are extrapolated from 1 to $3 \mathrm{~h}$ experiments; cf. Grossnickle 1978, Gorokhova \& Hansson in press).

The maximum food consumption of an animal is curtailed by physical limitations: prey handling time or physiological constraints such as gut passage time. The average individual prey handling time for the calanoid copepod Diaptomus minutus by Mysis relicta was $18.4 \mathrm{~s}$ (Ramcharan et al. 1985). Neomysis mercedis, slightly smaller (length $13 \mathrm{~mm}$ ) than our $M$. mixta (15 to $17 \mathrm{~mm}$ ), handled cladocerans (Daphnia) twice the size of our average zooplankton in $1.4 \mathrm{~min}$ (Chigbu \& Sibley 1994). As our calanoid copepods are larger than D. minutus but smaller than Daphnia, a handling time of $60 \mathrm{~s}$ per individual prey seems reasonable. From this, a maximum consumption range of 1440 calanoids mysid ${ }^{-1} \mathrm{~d}^{-1}$ or $>1 \mathrm{~g} \mathrm{C} \mathrm{g}^{-1} \mathrm{C} \mathrm{d}^{-1}$ can be expected, which exceeds our range of estimates of the maximum daily food consumption. Hence, $M$. mixta most likely is not limited by handling time but by other processes.

The functional response relationships described above, together with in situ growth data, can be used to evaluate the mysid's natural feeding conditions. From a review on mysid data from the present study area (Rudstam \& Hansson 1990), specific daily growth rate in August can be estimated at 0.02 , and a $7 \mathrm{mg}$ dry wt Mysis mixta would thus grow $0.14 \mathrm{mg}$ in $1 \mathrm{~d}$. In his bioenergetics analyses for $M$. mixta in this area, Rudstam (1989) found a growth conversion efficiency of $26 \%$ based on energy. From this, and assuming that the carbon to energy ratio is roughly the same in mysids as in its main food (crustacean zooplankton), the in situ food consumption can be estimated at $0.08 \mathrm{~g}$ $\mathrm{C} \mathrm{g}^{-1} \mathrm{C} \mathrm{d}^{-1}$. This consumption rate is lower than the maximum consumption rates found in our experiments, supporting our earlier conclusion based on in situ growth. (Hansson et al. 1990b), that Baitic M. mixta is food limited.

Based on the functional responses shown in Fig. 2, zooplankton densities needed to meet this in situ consumption $\left(0.08 \mathrm{~g} \mathrm{C} \mathrm{g}^{-1} \mathrm{C} \mathrm{d}^{-1}\right)$ can be estimated as 140 to $240 \mu \mathrm{g} \mathrm{Cl}^{-1}$, which is roughly 3.5 to 6 times the ambient zooplankton density (40 $\mu \mathrm{g} \mathrm{C} \mathrm{l}^{-1}$ ). Errors in the bioenergetics model cannot explain this discrepancy, as consumptions predicted from our data and assumed ambient zooplankton densities would be 0.01 to $0.03 \mathrm{~g} \mathrm{C}$ $\mathrm{g}^{-1} \mathrm{C} \mathrm{d}^{-1}$ and would result in growth efficiencies over $100 \%$. Another possible explanation is errors in the functional response. As it is hard to determine a functional response without interfering in some way with the mysids or their prey, such errors are difficult to evaluate. A likely explanation to the discrepancy is, however, that zooplankton have a small-scale patchy distribution which is exploited by the mysids and allows them to have a higher food consumption rate than expected from the average zooplankton abundance. The importance of this aspect of food patchiness has previously been discussed and described for various organisms, from plankton to marine mammals (e.g. Morris 1987, Rose \& Leggett 1990, Brandt et al. 1992, Noda et al. 1992, Folt et al. 1993, Goyke \& Brandt 1993, Saiz et al. 1993, Tiselius et al. 1993, Boyd 1996). Another possibility is that Mysis mixta, more than previously thought, uses alternative food sources such as phytoplankton, rotifers, and nanoplankton which are difficult to detect in the stomachs. This explanation is supported by nitrogen isotope analyses of mysids and their zooplankton prey (Hansson et al. in press).

There was a significant variation in capture rates $\left(k_{1}\right)$ for the different prey categories (Kruskal-Wallis test, $\chi^{2}=15.5, \mathrm{df}=5, \mathrm{p}<0.01$; estimated with SPSS for Windows release 7.0). Pairwise tests between prey group had, however, low power due to few observations per group. In general, Pseudocalanus juveniles and Acartia adults were consistently 'preferred' prey (Fig. 3). Bosmina and juveniles of Acartia also had relatively 


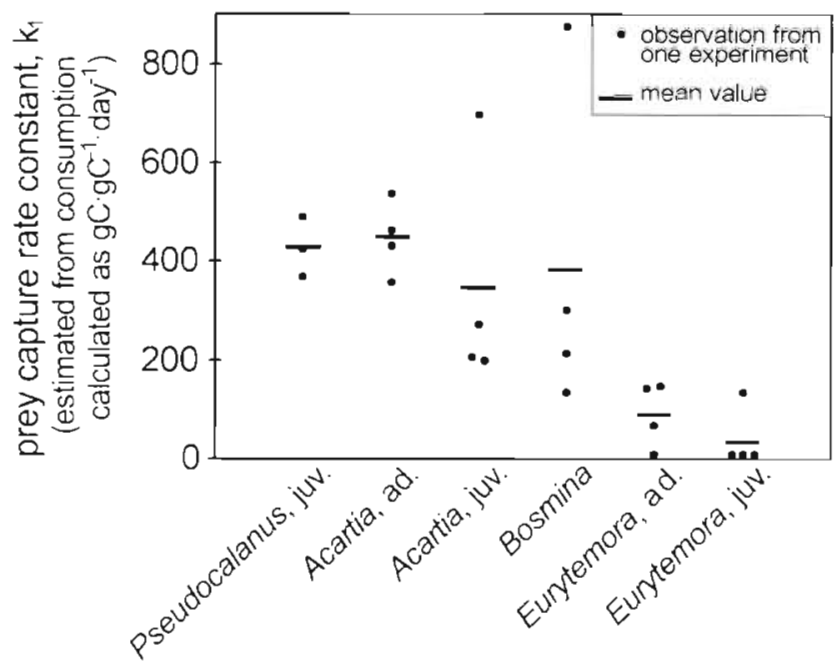

Fig. 3. Prey 'preferences' of Mysis mixta for different prey groups, expressed as prey capture rate constants $\left(k_{1}\right)$ estimated from the relationship $C R=k_{1} \times Z_{\text {mean }}+k_{1}$ where $C R$ is the consumption rate, $Z_{\text {mean }}$ is the prey abundance and $k_{1}$ and $k$ are constants

high average $k_{1}$ values, but the variation among experiments was considerable. Consistently low capture rates were shown for both adults and juveniles of Eurytemora (both groups had statistically significantly lower $k_{1}$ values than Pseudocalanus and Acartia: Mann-Whitney test, $U=0, \mathrm{p}<0.05$; estimated with SPSS for Windows release 7.0). This order of 'preferences' was the same, whether based on biomass capture rates ( $\mathrm{g} \mathrm{C} \mathrm{g}^{-1} \mathrm{C} \mathrm{d}^{-1}$ ) or number of prey consumed per mysid. These preferences differ from field data from this study area according to which Bosmina was the highest ranked prey, and Eurytemora more preferred than Acartia (Rudstam et al. 1989, 1992, based on analyses of simultaneously sampled zooplankton abundances and mysid stomach content; Pseudocalanus was not included in these studies as it was very uncommon in the samples). One possible explanation for the disagreement in order between Acartia and Eurytemora is that mysids in situ may forage in patches of zooplankton and that the zooplankton species composition in such patches are poorly represented by zooplankton samples integrating large volumes of water. In the stomachs analyzed by Rudstam et al. (1989, 1992) there was a large proportion of unidentifiable material, and if Acartia is more easily digested than Eurytemora, this could also have skewed these earlier estimates of preferences.

The prey selectivity of Mysis relicta has been studied repeatedly (Cooper \& Goldman 1980, Bowers \& Vanderploeg 1982, Grossnickle 1982, Ramcharan et al. 1985). In general, it has been reported that 'selected' prey often are small and slow or have less effective predator escape responses, and the order of prey selectivity is generally cladocerans > copepod nauplii and copepodites $>$ adult cyclopoid and calanoid copepods. Our results disagree with these findings for $M$. relicta, as $M$. mixta preferred large copepods (Pseudocalanus juveniles and adult Acartia) over the cladocerans, and large copepods over small copepods.

In conclusion, we have shown that Mysis mixta in the Baltic Sea is food limited even during the annual latesummer peak in zooplankton abundance. This supports our earlier finding (Hansson et al, 1990b), which was based on the correlation between in situ growth rates and zooplankton abundances. Furthermore our study suggests that $M$. mixta is able to exploit patches of zooplankton where the abundances are considerably higher than indicated by traditional zooplankton samples. $M$. mixta is a selective predator with the following order of prey preference: Pseudocalanus juveniles $\approx$ Acartia adults $\geq$ Bosmina $\approx$ Acartia juveniles $>$ Eurytemora adults $\approx$ Eurytemora juveniles.

Acknowledgements. This study was supported by grants to S.H. from the Swedish Natural Science Research Councll. The study was done at the Asko Laboratory, the field station of the Stockholm University Center for Marine Research, where the staff supported us in many ways.

\section{LITERATURE CITED}

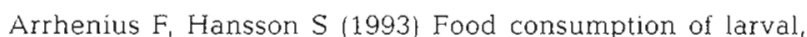
young, and adult herring and sprat in the Baltic Sea. Mar Ecol Prog Ser 96:125-137

Begon M, Harper JL, Townsend CR (1990) Ecology: individuals, populations and communities, 2nd edn. Blackwell Scientific Publications, Boston

Bowers JA, Vanderploeg HA (1982) In situ predatory behavior of Mysis relicta in Lake Michigan. Hydrobiologia 93: $121-131$

Boyd IL (1996) Temporal scales of foraging in a marine predator. Ecology 77:426-434

Brandt SB, Mason DM. Patrick EV (1992) Spatially-explicit models of fish growth rate. Fisheries 17:23

Carpenter S, Kitchell J, Hodgson J (1985) Cascading trophic interactions and lake productivity. BioSci 35:634-639

Chesson J (1983) The estimation and analysis of preference and its relationship to foraging models. Ecology 64: $1297-1304$

Chigbu P. Sibley TH (1994) Predation by Neomysis mercedis: effects of temperature, Daphnia magna size and prey density on ingestion rate and size selectivity. Freshwat Biol 32: $39-48$

Cooper SD, Goldman CR (1980) Opossum shrimp (Mysis relicta) predation on zooplankton. Can J Fish Aquat Sci 37:909-919

Cooper SD, Goldman CR (1982) Environmental factors affecting predation rates of Mysis relicta. Can J Fish Aquat Scl 39:203-208

Elmgren R (1984) Trophic dynamics in the enclosed, brackish Baltic Sea. Rapp PV Réun Cons Int Explor Mer 183: $152-169$

Folt C. Schulze PC, Baumgartner K (1993) Characterizing a zooplankton neighbourhood-small-scale patterns of 
association and abundance. Freshwat Biol 30:289-300

Gorokhova E, Hansson $S$ (in press) Effects of experimental conditions on the feeding rate of Mysis mixta (Crustacea, Mysidacea). Hydrobıologia

Goyke AP, Brandt SB (1993) Spatial models of salmonine growth rates in Lake Ontario. Trans Am Fish Soc 122: $870-883$

Grossnickle NE [1978) The herbivorous and predaceous habits of Mysis relicta in Lake Michigan. PhD thesis, Univ of Wisconsin, Madison

Grossnickle NE (1982) Feeding habits of Mysis relicta-an overview. Hydrobiologia 93:101-107

Hairston N, Smith F, Slobodkin L (1960) Community structure, population control and competition. Am Nat 94: $421-425$

Hairston NG Jr, Hairston NG Sr (1993) Cause-effect relationships in energy flow, trophic structure, and interspecific interactions. Am Nat 142:379-411

Hansson S, Elmgren R, Hobbie JE, Larsson U, Fry B, Johansson $S$ (in press) The stable nitrogen isotope ratio as a marker of food web interactions and fish migration. Ecology

Hansson S, Larsson U, Johansson S (1990a) Selective predation by herring and mysids, and zooplankton community structure in a Baltic Sea coastal area. J Plankton Res 12: 1099-1116

Hansson S, Rudstam LG, Johansson S (1990b) Are marine planktonıc invertebrates food limited? The case of Mysis mixta (Crustacea, Mysidacea) in the Baltic Sea. Oecologia $84: 430-432$

Hernroth L, Ackefors H (1979) The zooplankton of the Baltic proper. A long-term investigation of the fauna, its biology and ecology. Fisheries Board of Sweden, Institute of Marine Research, Lysekil, Report no. 2

Holling CS (1959) Some characteristics of simple types of predation and parasitism. Can Entomol 91:385-398

Huntley $M$ (1996) Temperature and copepod production in the sea: a reply. Am Nat 148:407-420

Huntley $M$, Boyd C (1984) Food-limited growth of marine zooplankton. Am Nat 124:455-478

Huntley ME, Lopez MDG (1992) Temperature-dependent production of marine copepods - a global synthesis. Am Nat 140:201-242

Ivlev VS (1961) Experimental ecology of the feeding of fishes. Yale University Press, New Haven

Johansson S, Hansson S, Araya-Nuñez O (1993) Temporal and spatial variation of coastal zooplankton in the Baltic Sea. Ecography 16:167-173

Kankaala P (1987) Struclure, dynamics and production of mesozooplankton community in the Bothnuan Bay, related

This article was submitted to the editor to environmental factors. Int Rev Ges Hydrobiol 72 : $121-146$

Kleppel GS, Davis CS, Carter K (1996) Temperature and copepod growth in the sea: a comment on the temperature-dependent model of Huntley and Lopez. Am Nat 148: $397-406$

Lindeman RL (1942) The trophic-dynamic aspect of ecology. Ecology 23:399-418

Mauchline J (1980) The biology of mysids and euphausids, Part One, The biology of mysids. In: Blaxter JHS, Russell FS, Yonge $M$ (eds) Advances in marine biology, 18. Academic Press, London, p 1-369

Morris DW (1987) Ecological scale and habitat use. Ecology 68:362-369

Noda M, Kawabata K, Gushima K, Kakuda S (1992) Importance of zooplankton patches in foraging ecology of the planktivorous reef fish Chromis chrysurus (Pomacentridae) at Kuchinoerabu Island, Japan. Mar Ecol Prog Ser 87 : $251-263$

Ramcharan CW, Sprules GW, Nero RW (1985) Notes on the tactile feeding behaviour of Mysis relicta Lovèn (Malacostraca: Mysidacea). Verh Int Verein Limnol 22:3215-3219

Rose GA, Leggett WC (1990) The importance of scale to predator-prey spatial correlations: an example of Atlantic fishes. Ecology 71:33-34

Rudstam LG (1989) A bioenergetic model for Mysis growth and consumption applied to a Baltic population of Mysis mixta. J Plankton Res 11:971-983

Rudstam, LG, Danielsson K, Hansson S, Johansson S (1989) Diel vertical migration and feeding patterns of Mysis mixta (Crustacea, Mysidacea) in the Baltic Sea. Mar Biol 101:43-52

Rudstam LG, Hansson S (1990) On the ecology of $M$. mixta (Crustacea, Mysidacea) in a coastal area of the northern Baltic proper. Ann Zool Fenn 27:259-263

Rudstam LG, Hansson S, Johansson S, Larsson U (1992) Dynamics of planktivory in a coastal area of the northern Baltic proper. Mar Ecol Prog Ser 80:159-173

Saiz E, Tiselius P, Jonsson PR, Verity P, Paffenhöfer GA (1993) Experimental records of the effects of food patchiness and predation on egg production of Acartia tonsa. Limnol Oceanogr 38:280-289

Tiselius P, Jonsson PR, Verity PG (1993) A model evaluation of the impact of food patchiness on foraging strategy and predation risk in zooplankton. Bull Mar Sci 53:247-264

Toda H, Arima T, Takahashi M, Ichimura S (1987) Physiological evaluation of temperature effect on the growth processes of the mysid, Neomysis intermedia Czerniawsky. J Plankton Res 9:51-63

Manuscript first received: December 12, 1996

Revised version accepted: February 24, 1997 